\title{
Teaching Taxation: A Comprehensive Method
}

\author{
Tao Zeng \\ Wilfrid Laurier University \\ Email: tzeng@wlu.ca
}

\begin{abstract}
In this paper, I have shared the method that has been used in my tax classes. The method is a comprehensive method, to the extent that in classes, I use tax cases including court cases and real world cases, and share empirical results from my tax researches in my teaching. The purpose of using such a comprehensive method is based on my belief that teaching is about facilitating learning for all students, motivating students' interest, and preventing students from narrowly focusing on one perspective, i.e., the textbook.
\end{abstract}

Keywords: teaching taxation, comprehensive method, cases

\section{INTRODUCTION}

At the School of Business and Economics, Wilfrid Laurier University, there are two tax courses provided at the undergraduate level. They are, Taxation I - an intensive study of the Canadian Income Tax Act and related statutes; and Advanced Taxation - an extension of Taxation I and its application to corporations, partnerships and other organizations. There is one tax course provided at the MBA level for both Waterloo and Toronto (MBA-CMA) campus. It is Managerial Tax Planning - emphasis on tax planning for individuals, partnerships and corporations. This course familiarizes students with relevant tax rules, and how they are applied in day-to-day decisions faced by general managers and decision makers.

Generally speaking, the tax courses provided for business students are studies of the Canadian Income Tax Act and its application to the taxation of persons and corporations. Having taught taxes for more than ten years for all the three tax courses, I'd like to share the method I use in my classes comprehensive method.

I have the view that the students should not be immersed in the technical jargon and details of income tax law without a clear idea of what happened in a real world and how to use the knowledge to solve a practical tax problem. The memorization of a large number of separate tax rules does not provide a sound understanding of income tax issues. The knowledge of such rules is only meaningful when the students get to know about how to apply it in the real world. To achieve the above goal, I use a comprehensive method to teach taxation, that is, I use tax cases (including court cases and real world cases), share empirical results from my tax researches, and use both lectures and videos in my classes.

\section{Tax cases}

To facilitate learning and applying knowledge for all students and stimulate students' interest, I use many cases in my classes. The cases are selecting from court cases and a real world tax problem.

\section{Real world tax problems:}

When I discuss income tax legislation on investment income, I remind the students of the fact that the investors should make investment decision based on their after-tax return rather than before-tax return. I provide a example as follows.

Problem. It is January 1st, 2011. You have $\$ 5,000$ in your checking account and plan to make an investment. After talking with your financial investment advisor, you are interested in two mutual funds: an Canadian income fund with annual interest rate of $4 \%$, and Canadian dividend fund with annual dividend yield of 3\%. Which mutual fund should you choose? What factors other than tax liability will affect your decision?

When I cover the lecture of tax liability for partnership or other organizations, I provide a problem related to the situation if the students plan to start a business, what organization would they choose and how tax treatment affect their choice.

\section{Court case: Manufacturing and Processing (M\&P)}

The company was in the cable television industry. Its activities included intercepting and capturing electromagnetic waves and signals for transmission to customers. It claimed that before the transmission, the electromagnetic waves and signals were selectively gathered and purified, which constituted the "processing in Canada goods for sale". The Minister disallowed the M\&P profits reduction.

Form time to time, I refer to prior court cases to explain relevant tax concept and rules. Foe example, when I 
discuss the credit for manufacturing and processing profit, I use the following case.

I find that adding tax cases for the students to discuss attracted attention and interest. The students are interested in these cases and eager to discuss them.

\section{Empirical results from prior researches}

In order to let the students have an idea about how tax rules affect the real world as well people's daily life, I often present the empirical results from my prior researches.

At the time I discuss the capital gains exemption and the reaction from the capital market, I display the following results from my prior research.

Research 2. Stock market reactions and capital gains tax: Evidence from the 1985 Canadian lifetime capital gains exemption

The Canadian federal government budget of May 23, 1985 provided individual taxpayers with a cumulative tax exemption for capital gains, up to a lifetime limit of $\$ 500,000$. The empirical results, using daily stock return and trading volume data from the Toronto Stock Exchange, show that stock prices decreased three days before the announcement of the lifetime capital gains exemption. The empirical results also show that stock trading volume increased two days and four days before the announcement and five days following the announcement. These results are consistent with the argument that the capital gains tax constrained some individual shareholders from selling appreciated shares (often called "lock-in effect"). In summary, we find that stock returns decrease, which suggests downward price pressure in response to this capital gains tax relief. Shares with potential capital gains experience decreasing prices and increasing trading volume. Hence, we conclude that capital gains taxation constrains some individual shareholders from selling shares.

\section{Lectures and Videos}

I think that student attention must be considered. Variety in the presentation is essential to maintain interest. Variations in manner and style are helpful. I plan to use both lectures and videos to delivered the topics, and make variety of class presentations, for example, I plan to make movies to deliver lectures using xtranormal.com website. The website allows people to make movies based on typing. On the website, you will make your own teaching movies. The characters, which is created on the movie, can talk based on the typed scripts.

In summary, teaching is an ongoing process of reflection and revision, and there is always a room for improvement. It benefits the students as well as the instructor (learning by teaching) to improve teaching.

\section{ACKNOWLEDGEMENT}

The author gratefully acknowledges the financial supports for this research were received from CA/Laurier Research Centre and a grant partly funded by WLU Operating funds and partly by SSHRC Institutional Grant awarded to WLU

\section{REFERENCE}

[1] Cole, C.C., "To Improve Instruction", American Association for Higher Education, 1978.

[2] Eble, K.E., The Craft of Teaching, San Francisco, CA:Jossey-Bases, 1988.

[3] Huot, R., Understang IncomeTax, Carswell, 2001.

[4] Seldin, $\quad$ P., $\quad \begin{gathered}\text { Improve } \\ \text { http://www.olemiss.edu/vc academic affairs/improve.html. }\end{gathered}$

[5] Lin, Horn-chern and T. Zeng, "Individuals' Registered Retirement Savings Plan (RRSP) Participation and Contribution: Evidence from CCRA's Income Statistics for the Years 1996-99”, Business Review, Cambridge 6(2), 126-131, 2006.

[6] - "Stock Market Reactions and Capital Gains Tax: Evidence from the 1985 Canadian Lifetime Capital Gains Exemption", Review of Accounting and Finance 4(2), 149-164, 2005

[7] Teaching Tips - Faculty Development, http://honolulu.hawaii.edu/intranet/committees/facDevCom/guidebk/t eachtip/teachtip.htm.

[8] Ten Ways to Make Your Teaching More Effective, University of California, Berkely, Office of Educational Development.

[9] Zeng, T., 2008, Tax Education in Business, "Tax Education in Business", the 8th China International Academic Seminar for Universities (excellent paper). 